\title{
GCKR gene functional variants in type 2 diabetes and metabolic syndrome: do the rare variants associate with increased carotid intima-media thickness?
}

Márton Mohás ${ }^{*}$, Péter Kisfali², Luca Járomi², Anita Maász², Eszter Fehér ${ }^{3}$, Veronika Csöngei² ${ }^{2}$ Noémi Polgár², Enikő Sáfrány ${ }^{2}$, Judit Cseh', Katalin Sümegi², Katalin Hetyésy ${ }^{4}$, István Wittmann', Béla Melegh²

\begin{abstract}
Background: Recent studies revealed that glucokinase regulatory protein (GCKR) variants (rs780094 and rs1260326) are associated with serum triglycerides and plasma glucose levels. Here we analyzed primarily the association of these two variants with the lipid profile and plasma glucose levels in Hungarian subjects with type 2 diabetes mellitus and metabolic syndrome; and also correlated the genotypes with the carotid intima-media thickness records.
\end{abstract}

Methods: A total of 321 type 2 diabetic patients, 455 metabolic syndrome patients, and 172 healthy controls were genotyped by PCR-RFLP.

Results: Both GCKR variants were found to associate with serum triglycerides and with fasting plasma glucose. However, significant association with the development of type 2 diabetes mellitus and metabolic syndrome could not be observed. Analyzing the records of the patients, a positive association of prevalence the GCKR homozygous functional variants and carotid intima-media thickness was found in the metabolic syndrome patients.

Conclusions: Our results support that rs780094 and rs1260326 functional variants of the GCKR gene are inversely associated with serum triglycerides and fasting plasma glucose levels, as it was already reported for diabetic and metabolic syndrome patients in some other populations. Besides this positive replication, as a novel feature, our preliminary findings also suggest a cardiovascular risk role of the GCKR minor allele carriage based on the carotid intima-media thickness association.

\section{Background}

Type 2 diabetes mellitus (T2DM) is characterized by elevated plasma glucose level as a result of impaired beta-cell function and/or peripheral insulin resistance [1]. Impaired glucose regulation is a major hallmark of metabolic syndrome (MS), however it is a more complex disorder featured by visceral obesity, elevated serum triglycerides, low level of HDL-cholesterol and raised blood pressure [2]. The prevalence of T2DM and MS is very high in the industrialized countries contributing to

\footnotetext{
* Correspondence: mohasmarton@gmail.com

'2nd Department of Medicine and Nephrological Center, University of Pécs, Pécs, Hungary H-7624 Pacsirta 1

Full list of author information is available at the end of the article
}

a considerably increased atherosclerotic burden and cardiovascular risk. Both of them are multifactorial diseases, besides several environmental factors, such as cigarette smoking, obesity, lack of exercise, bad nutrition habits and genetic factors are also contributed to the pathogenesis.

Glucokinase (GCK) is a predominant glucose phosphorylating enzyme expressed in the liver and in the beta-cells of the Langerhans islets, playing a pivotal role in the glucose-stimulated insulin release as a physiological glucose-sensor [3]. Pancreatic islets and the liver contain a regulatory protein (glucokinase regulatory protein, GCKR), which inhibits GCK in an allosteric manner with respect to glucose concentration by 
forming an inactive heterodimer. The inhibitory effect of GCKR is enhanced by fructose-6-phosphate and antagonized by fructose-1-phosphate [4]. The $27 \mathrm{~kb}$ GCKR gene is located on chromosome 2p23 containing 19 exons and encodes a $68 \mathrm{kDa}$ protein [5,6]. Genomewide association studies showed, that common functional variants of the GCKR gene are associated with fasting plasma glucose, insulin levels, and both serum triglycerides and low/high-density lipoprotein cholesterol levels, thus, single nucleotide polymorphisms (SNPs) rs780094 and rs1260326 reduce fasting plasma glucose concentration and insulin levels and improve insulin resistance, while inversely increase fasting and postprandial serum triglycerides [7-16]. More recently, both functional variants of the GCKR gene were widely investigated as candidate T2DM susceptibility variants, and a protective nature against T2DM $[8,10,17,18]$.

The primary goal of the current work was to study the possible association of rs780094 and rs1260326 of the GCKR gene on metabolic and cardiovascular risk traits in Hungarian patients, which nation differs from the surrounding European populations in its origin [19]. The pooled ultrasonography records of the patients enabled us to study also the carotid intima-media thickness association.

\section{Methods}

\subsection{Study population}

In a genetic association study we examined two common variants (rs780094 and rs1260326) of the GCKR gene. The study population comprised 321 subjects with T2DM (172 males, 149 females, mean age: $61.3 \pm$ 12.2 years, range: $27-89$ years), 455 subjects with MS (200 males, 255 females, mean age: $61.7 \pm 10.7$, range: 26-85 years) and 172 healthy control subjects (49 males, 123 females, mean age: $56.5 \pm 15.2$, range: $19-92$ years). All 948 study participants were selected from the Caucasian Hungarian population.

All patients were enrolled from the $2^{\text {nd }}$ Department of Medicine and Nephrological Center, University of Pécs, Hungary and from the Aladár Petz Hospital, Győr, Hungary. T2DM was diagnosed according to the criteria of the World Health Organization [1]. Waist circumference data were not available, therefore MS was diagnosed according to modified criteria of the Adult Treatment Panel III of National Cholesterol Education Program [20], defined as presence of at least 3 of the following factors at the time of diagnosis: body mass index $(\mathrm{BMI})>30 \mathrm{~kg} / \mathrm{m}^{2}$, serum triglycerides $\geq 1.70$ $\mathrm{mmol} / \mathrm{l}$ and/or lipid lowering treatment; serum HDLcholesterol $<0.9 / 1.1 \mathrm{mmol} / \mathrm{l}$ (male/female); systolic blood pressure $\geq 130 \mathrm{mmHg}$ and diastolic blood pressure $\geq 85$ $\mathrm{mmHg}$ and/or antihypertensive treatment; fasting plasma glucose $\geq 5.60 \mathrm{mmol} / \mathrm{l}$ and/or antiglycemic treatment. Hypertriglyceridemia was defined as fasting serum triglycerides $\geq 1.7 \mathrm{mmol} / \mathrm{l}$. Controls were gathered from trauma units, blood donors, medical staff and university students, they were free from any single clinical or laboratory sign of T2DM or MS; their medical history were also free from any systemic or organ-specific disease. Exclusion criteria were as follows: pregnancy, fever, sepsis, malignancies, autoimmune systemic diseases, alcohol or drog abuse, severe heart failure, hepatic failure.

DNA samples and the clinical data were deposited into the Central Biobank governed by the University of Pécs, as part of the National Biobank Network of Hungary http:// www.biobank.hu, approved by the national Scientific Research Ethics Committee (ETT TUKEB). The Biobank belongs to the pan-European Biobanking and Biomolecular Resources Research Infrastructure (BBMRI) preparatory phase project http://bbmri.eu/bbmri/. All participants gave their informed consent and the study followed the principles of the Helsinki Declaration.

\subsection{Biochemical and clinical data}

All participants underwent a detailed medical examination, including anamnestic history, physical examination, and estimation of cardiovascular risk factors, laboratory and urine analysis, electrocardiography. Laboratory parameters were assessed using routine methods from fasting blood samples. BMI was calculated as weight $(\mathrm{kg})$ divided by height $\left(\mathrm{m}^{2}\right)$. Carotid intima-media thickness (CIMT) was measured by B-mode ultrasound device with a high resolution $10 \mathrm{MHz}$ linear transducer (ALOKA 4000, Tokyo, Japan) in a plaque free region of both carotid arteries at $2 \mathrm{~cm}$ proximal to the carotid bulb on the common carotid artery and at the origin of the internal carotid artery. The ultrasound transducer was placed in an angle of $90^{\circ}$ of the vessel wall. CIMT values were obtained from the above mentioned sites and were defined as means of the maximal CIMT measurements for the right and left sides. Each participants were scanned in a standardized environment, in the same room, by the same examiner, using the same instrument.

\subsection{Genotyping}

DNA was isolated from peripheral blood leukocytes by standard salting out method. For polymerase chain reaction amplification, the following primers (MWG-Biotech AG, Ebersberg, Germany) were used: GCKR rs1260326: forward 5'-TGC AGA CTA TAG TGG AGC CG-3' and reverse 5'-CAT CAC ATG GCC ACT GCT TT-3'; GCKR rs780094: forward 5'-GAT TGT CTC AGG CAA ACC TGG TAG-3' and reverse 5'-CTA GGA GTG GTG GCA TAC ACC TG-3'. An MJ Research PTC-200 thermal cycler (Bio-Rad, Hercules, CA, USA) was used 
for the amplification. PCR conditions were the following: predenaturation at $96^{\circ} \mathrm{C}$ for $2 \mathrm{~min}$; followed by 35 cycles of denaturation at $96^{\circ} \mathrm{C}$ for $20 \mathrm{sec}$ (rs1260326), 30 cycles of denaturation at $96^{\circ} \mathrm{C}$ for $20 \mathrm{sec}$ (rs780094); annealing at $60^{\circ} \mathrm{C}$ for $20 \mathrm{sec}$ (rs1260326), and at $62^{\circ} \mathrm{C}$ for $30 \mathrm{sec}$ (rs780094); primer extension for $30 \mathrm{sec}$ at $72^{\circ} \mathrm{C}$; and final extension at $72^{\circ} \mathrm{C}$ for $5 \mathrm{~min}$. The amplicons were digested by HpaII restriction endonuclease (rs1260326) and PscI (rs780094) (Fermentas, Burlington, ON, Canada). The digestion of $231 \mathrm{bp}$ amplicon of rs1260326 CC genotype resulted in 18, 63, $150 \mathrm{bp}$ fragments; the TT genotype 18 and $213 \mathrm{bp}$; while the heterozygous genotype 18, 63, 150, 213 bp fragments. For the rs780094 $427 \mathrm{bp}$ amplicon the following fragments were detected: GG genotype 62, 177, $188 \mathrm{bp}$; AA genotype $62,365 \mathrm{bp}$; heterozygous genotype $62,177,188$, $365 \mathrm{bp}$ fragments. All methods were designed to include an obligate cleavage site on the amplicon to enable us to control the efficacy of the digestion.

\subsection{Statistical analysis}

BMI, fasting plasma glucose concentrations, serum triglycerides and HDL-cholesterol levels were log-transformed because of non-normal distribution. Results were expressed as mean $\pm \mathrm{SD}$ and median (minimummaximum) as appropriate according to distribution. Kolmogorov-Smirnov test was used to assess sample distribution. Chi-square test was carried out to determine whether genotype distributions followed the HardyWeinberg equilibrium and to compare other qualitative data. Clinical and biochemical characteristics of the study participants at baseline were compared with one-way ANOVA. Statistical differences between the individual GCKR genotypes were assessed by analysis of covariance (ANCOVA) adjusted for gender, age, BMI. Trend was examined with Jonckheere-Terpstra test. Logistic regression analysis models were used to evaluate individual effects of genotypes as possible risk factors; multivariate regression analysis models were adjusted for age, gender, total serum cholesterol, coronary artery diseases (CAD) and statin therapy. All statistical procedures were performed using the SPSS 15.0 software (SPSS Inc., Chicago, IL, USA). P values $\leq 0.05$ were considered statistically significant.

\section{Results}

Major clinical and biochemical features of the patients and controls are summarized in Table 1; the genotype profiles including the minor allele frequencies are shown in Table 2. All genotypes were in HardyWeinberg equilibrium. Allele frequencies were similar in the study groups.

Table 3 shows the lipid parameters examined, the plasma glucose concentrations, BMI, and CIMT data for each analyzed SNP of the GCKR gene. BMI is not associated either with rs780094 or with rs1260326, however plasma glucose levels were associated with both variants significantly $(\mathrm{p}<0.05)$. We observed association of the minor allele of rs780094 and rs1260326 with elevated serum triglycerides in all groups. We found no relationship between variants of GCKR gene and total serum cholesterol levels, however HDL-cholesterol level was significantly lower in subjects homozygous for the minor allele for both rs780094 and rs1260326, but only in T2DM patients, moreover LDL-cholesterol was significantly elevated in homozygous patients, but only in the MS group. We also correlated the CIMT of the patients with T2DM and MS. The homozygous minor alleles were associated with increased carotid intima-media thickness in metabolic syndrome patients.

Table 4. shows the relative risk of hypertriglyceridemia for variants rs780094 and rs1260326 at GCKR gene calculated by the multiple logistic regression analysis models. Regression analysis revealed that both rs780094 and rs 1260326 confer a significant susceptibility for the development of hypertriglyceridemia; after adjusting the results for age, gender, total serum cholesterol, CAD and statin therapy.

\section{Discussion}

Genome wide association studies revealed an association between SNP rs780094 of GCKR gene and hypertriglyceridemia in subjects with T2DM [12]. This association was replicated in other large diabetic and non-diabetic population samples $[10,13]$. Besides the triglyceride levels, the SNP was also associated with lower plasma glucose levels, and with lower risk for the development of T2DM [12,17]. Another SNP of GCKR (rs1260326, $\mathrm{P} 446 \mathrm{~L})$ is in strong linkage disequilibrium $\left(\mathrm{r}^{2}=0.96\right)$ with rs780094 according the HapMap II data http:// www.hapmap.org. In Danish diabetic twins and in the Dutch population rs1260326 was found to be associated with increased insulin secretion and lower plasma glucose $[7,21]$, and association with elevated triglycerides was also confirmed in different populations $[8,9]$. By contrast, the rs1260326 allele was found to correlate with metabolic traits, but not with susceptibility for the development of metabolic syndrome in the Scandinavian population [22].

In the current study, we could replicate the previously reported positive associations of the two functional variants of GCKR gene (rs780094 and rs1260326) and triglyceride/glucose metabolism in the Hungarian population; our results confirmed the inverse association with serum triglycerides and plasma glucose levels in T2DM, MS and healthy control subjects.

GCKR competitively inhibits GCK, playing a major role in the regulation of insulin secretion and glycogen 
Table 1 Clinical and biochemical features of the patients with T2DM, MS and control subjects.

\begin{tabular}{|c|c|c|c|c|}
\hline & $\begin{array}{l}\text { Controls } \\
n=172\end{array}$ & $\begin{array}{c}\text { T2DM } \\
\mathrm{n}=321\end{array}$ & $\begin{array}{c}\text { MS } \\
\mathrm{n}=455\end{array}$ & $\mathrm{p}$-value \\
\hline Gender (male/female) & $49 / 123$ & $172 / 149$ & $200 / 255$ & $<0.001$ \\
\hline Age (years) & $56.5 \pm 15.2$ & $61.3 \pm 12.2$ & $61.7 \pm 10.7$ & $<0.001^{*}$ \\
\hline Body mass index $\left(\mathrm{kg} / \mathrm{m}^{2}\right)$ & $23.9 \pm 2.15$ & $29.5 \pm 5.87$ & $33.3 \pm 5.48$ & $<0.001^{* \#}$ \\
\hline Fasting plasma glucose $(\mathrm{mmol} / \mathrm{l})$ & N/A & $8.70(2.30-22.8)$ & $9.00(3.00-30.8)$ & 0.249 \\
\hline Serum total cholesterol $(\mathrm{mmol} / \mathrm{l})$ & $4.78 \pm 1.10$ & $5.16 \pm 1.25$ & $5.37 \pm 0.94$ & $<0.001^{\dagger}$ \\
\hline Serum LDL-cholesterol (mmol/l) & N/A & $2.74 \pm 0.86$ & $2.83 \pm 0.84$ & 0.256 \\
\hline Serum HDL-cholesterol (mmol/l) & N/A & $1.19(0.55-2.12)$ & $1.23(0.55-2.49)$ & $<0.001$ \\
\hline Serum triglycerides (mmol/l) & $1.50(0.50-3.60)$ & $1.62(0.35-14.8)$ & $1.98(0.35-14.48)$ & $<0.001^{\#+}$ \\
\hline CIMT (mm) & N/A & $0.88 \pm 0.44$ & $1.22 \pm 0.74$ & 0.265 \\
\hline Systolic blood pressure $(\mathrm{mmHg})$ & N/A & $130(87.0-210)$ & $140(70.0-200)$ & $<0.001$ \\
\hline Diastolic blood pressure $(\mathrm{mmHg})$ & N/A & $80.0(50.0-130)$ & $80.0(60.0-137)$ & $<0.001$ \\
\hline Hypertension (\%) & 22.7 & 77.5 & 90.4 & $<0.001^{*}$ \\
\hline Coronary heart disease (\%) & 4.1 & 25.3 & 25.4 & $<0.001^{*}$ \\
\hline
\end{tabular}

CIMT, carotid intima-media thickness; HDL, high density lipoprotein; LDL, low density lipoprotein; N/A: data not available; MS: metabolic syndrome, T2DM: type 2 diabetes mellitus; ${ }^{*}$ Controls vs. T2DM and MS; \# T2DM vs. MS; + Controls vs. MS; Data are means \pm SD or median (minimum-maximum) as appropriate.

metabolism and considered as a potential susceptibility gene for T2DM. In the presence of low glucose concentrations both GCK and GCKR are localized in the nucleus of hepatocytes due to metabolic alterations (higher glucose or fructose concentrations) GCK, but not GCKR, translocates into the cytoplasm $[23,24]$. Furthermore, GCKR is also play a role in the nuclearcytoplasmic transport and in the protection against degradation of GCK [25-27]. Animal models have also shown that GCKR also regulates the posttranscriptional expression of GCK. Taken all these data together, it is obvious that functional change in this regulatory protein may considerably influence the glucose metabolism.

In SNP rs1260326 of the GCKR a C/T change results in a proline to leucine substitution in the amino sequence of the encoded protein. This change is very likely to modify the structure of the protein and if this structural alteration is in the binding site of fructose-6-

Table 2 Genotype distribution (case number) and allele frequencies (\%) in control subjects and in patients with T2DM and MS.

\begin{tabular}{ccccc}
\hline & & Controls & T2DM & MS \\
\hline $\begin{array}{c}\text { GCKR } \\
\text { (rs780094) }\end{array}$ & GG & 44 & 77 & 121 \\
& GA & 93 & 151 & 217 \\
& AA & 35 & 78 & 100 \\
& A allele (\%) & 47.4 & 46.9 & 47.6 \\
\hline GCKR & CC & 48 & 80 & 118 \\
(rs1260326) & CT & 80 & 155 & 219 \\
& TT & 44 & 63 & 91 \\
& T allele (\%) & 48.8 & 47.1 & 46.8 \\
\hline
\end{tabular}

T2DM: subjects with type 2 diabetes mellitus; MS: subjects with metabolic syndrome phosphate or fructose-1-phosphate it can influence the function of the protein.

Increased glycolitic flux, downregulated glucose-6phosphatase and upregulated GCK, phosphofructokinase and fatty acid synthase result in an increased glycogen synthesis and malonil-CoA concentration and an increased VLDL triglyceride production. These metabolic changes might potentially explain the lower plasma glucose and higher triglyceride levels, however the exact mechanism remains to be elucidated $[8,28]$.

Measuring CIMT, as a surrogate marker of cardiovascular disease, is widely used and validated method in both patients with or without T2DM to detect subclinical atherosclerosis, however to predict the relative risk for the development of future cardiovascular diseases is much more difficult and presumes holistic interpretation of the complex interactions between both genetic and clinical factors.

Besides the conventional cardiovascular risk factors as hypertension, high LDL-cholesterol level, low HDL-cholesterol level, hypertriglyceridemia, also the level of advanced glycation endproducts (e.g. Nepsilon-carboxymethyllysine) confer an independent significant risk for cardiovascular diseases and associated with atherosclerotic lesions not only in diabetic but in normoglycemic subjects [29-34].

Common variants in the GCKR gene were referred to be associated also with higher $\mathrm{C}$-reactive protein levels, which is a favorable atherosclerotic marker. Here we also investigated the lipid traits and the CIMT, which was proved an independent preclinical marker of atherosclerosis and CAD.

\section{Conclusions}

Our results support that rs780094 and rs1260326 functional variants of the GCKR gene are inversely 
Table 3 Body mass index, fasting plasma glucose, lipid profile and carotid intima-media thickness in subjects with metabolic syndrome, type 2 diabetes mellitus and controls by individual genotypes (A: GCKR rs780094; B: GCKR rs1260326)

\begin{tabular}{|c|c|c|c|c|c|c|c|c|c|c|}
\hline & & \multicolumn{3}{|c|}{ Controls } & \multicolumn{3}{|c|}{ T2DM } & \multicolumn{3}{|c|}{ MS } \\
\hline & & $\begin{array}{c}\text { GG } \\
n=44\end{array}$ & $\begin{array}{c}\mathrm{GA} \\
\mathrm{n}=93\end{array}$ & $\begin{array}{c}\text { AA } \\
n=35\end{array}$ & $\begin{array}{c}\text { GG } \\
n=77\end{array}$ & $\begin{array}{c}\text { GA } \\
\mathrm{n}=151\end{array}$ & $\begin{array}{c}A A \\
n=78\end{array}$ & $\begin{array}{c}\text { GG } \\
n=121\end{array}$ & $\begin{array}{c}\text { GA } \\
n=217\end{array}$ & $\begin{array}{c}A A \\
n=100\end{array}$ \\
\hline & BMI $\left(\mathrm{kg} / \mathrm{m}^{2}\right)$ & $\begin{array}{c}23.6 \\
(21.2-28.6)\end{array}$ & $\begin{array}{c}23.9 \\
(15.8-32.8)\end{array}$ & $\begin{array}{c}23.8 \\
(13.7-26.8)\end{array}$ & $\begin{array}{c}29.2 \\
(17.0-48.6)\end{array}$ & $\begin{array}{c}29.0 \\
(18.3-45.9)\end{array}$ & $\begin{array}{c}27.3 \\
(18.3-43.4)\end{array}$ & $\begin{array}{c}32.5 \\
(22.5-52.5)\end{array}$ & $\begin{array}{c}32.7 \\
(20.4-48.1)\end{array}$ & $\begin{array}{c}32.9 \\
(19.4-60.5)\end{array}$ \\
\hline & $\mathrm{FPG}(\mathrm{mmol} / \mathrm{l})$ & N/A & N/A & N/A & $\begin{array}{c}9.50 \\
(3.00-17.0)\end{array}$ & $\begin{array}{c}9.20 \\
(3.80-22.8)\end{array}$ & $\begin{array}{c}8.90 \\
(2.30-17.1)^{*}\end{array}$ & $\begin{array}{c}9.60 \\
(3.80-19.1)\end{array}$ & $\begin{array}{c}8.80 \\
(3.00-30.8)\end{array}$ & $\begin{array}{c}8.50 \\
(4.51-16.6)^{*}\end{array}$ \\
\hline & $\begin{array}{l}\text { Serum triglycerides } \\
(\mathrm{mmol} / \mathrm{l})\end{array}$ & $\begin{array}{c}1.35 \\
(0.50-2.90)\end{array}$ & $\begin{array}{c}1.50 \\
(0.80-3.60)\end{array}$ & $\begin{array}{c}1.70 \\
(0.70-3.20)^{*}\end{array}$ & $\begin{array}{c}1.77 \\
(0.38-8.23)\end{array}$ & $\begin{array}{c}1.81 \\
(0.35-6.22)\end{array}$ & $\begin{array}{c}2.24 \\
(0.66-14.8)^{*}\end{array}$ & $\begin{array}{c}2.07 \\
(0.49-7.76)\end{array}$ & $\begin{array}{c}2.68 \\
(0.35-14.2)^{*}\end{array}$ & $\begin{array}{c}3.07 \\
(0.78-12.3) \#\end{array}$ \\
\hline \multirow[t]{9}{*}{$A$} & $\begin{array}{l}\text { Serum total-cholesterol } \\
(\mathrm{mmol} / \mathrm{l})\end{array}$ & $5.48 \pm 0.80$ & $5.44 \pm 0.94$ & $5.04 \pm 1.04$ & $5.01 \pm 1.02$ & $4.60 \pm 1.12$ & $4.75 \pm 1.10$ & $5.03 \pm 1.05$ & $5.15 \pm 1.36$ & $5.35 \pm 1.26$ \\
\hline & $\begin{array}{l}\text { Serum HDL-cholesterol } \\
(\mathrm{mmol} / \mathrm{l})\end{array}$ & N/A & N/A & N/A & $\begin{array}{c}1.39 \\
(0.76-2.48)\end{array}$ & $\begin{array}{c}1.25 \\
(0.68-2.37)\end{array}$ & $\begin{array}{c}1.19 \\
(0.62-2.49)^{*}\end{array}$ & $\begin{array}{c}1.21 \\
(0.77-1.99)\end{array}$ & $\begin{array}{c}1.22 \\
(0.55-2.12)\end{array}$ & $\begin{array}{c}1.17 \\
(0.79-1.88)\end{array}$ \\
\hline & $\begin{array}{l}\text { Serum LDL-cholesterol } \\
(\mathrm{mmol} / \mathrm{l})\end{array}$ & N/A & N/A & N/A & $2.84 \pm 0.90$ & $2.64 \pm 0.83$ & $2.75 \pm 0.89$ & $2.08 \pm 0.81$ & $2.70 \pm 0.83$ & $3.06 \pm 0.92^{*}$ \\
\hline & CIMT $(m m)$ & N/A & N/A & N/A & $0.81 \pm 0.42$ & $0.86 \pm 0.38$ & $0.95 \pm 0.44$ & $0.79 \pm 0.28$ & $0.87 \pm 0.32$ & $1.06 \pm 0.26^{*}$ \\
\hline & & \multicolumn{3}{|c|}{ Controls } & \multicolumn{3}{|c|}{ T2DM } & \multicolumn{3}{|c|}{ MS } \\
\hline & & $\begin{array}{c}C C \\
n=48\end{array}$ & $\begin{array}{c}\text { TC } \\
\mathrm{n}=80\end{array}$ & $\begin{array}{c}\pi \\
n=44\end{array}$ & $\begin{array}{c}C C \\
n=80\end{array}$ & $\begin{array}{c}\text { TC } \\
\mathrm{n}=155\end{array}$ & $\begin{array}{c}T T \\
n=63\end{array}$ & $\begin{array}{c}C C \\
n=118\end{array}$ & $\begin{array}{c}\text { TC } \\
\mathrm{n}=219\end{array}$ & $\begin{array}{c}T T \\
\mathrm{n}=91\end{array}$ \\
\hline & $\mathrm{BMI}\left(\mathrm{kg} / \mathrm{m}^{2}\right)$ & $\begin{array}{c}23.7 \\
(20.8-28-6)\end{array}$ & $\begin{array}{c}23.8 \\
(15.8-32.8)\end{array}$ & $\begin{array}{c}23.8 \\
(13.7-26.8)\end{array}$ & $\begin{array}{c}29.2 \\
(17.0-37.6)\end{array}$ & $\begin{array}{c}29.3 \\
(18.3-45.9)\end{array}$ & $\begin{array}{c}28.9 \\
(18.3-38.6)\end{array}$ & $\begin{array}{c}31.8 \\
(20.4-49.57)\end{array}$ & $\begin{array}{c}32.8 \\
(19.4-52.5)\end{array}$ & $\begin{array}{c}33.4 \\
(25.0-60.5)\end{array}$ \\
\hline & FPG (mmol/l) & N/A & N/A & N/A & $\begin{array}{c}9.05 \\
(3.00-16.9)\end{array}$ & $\begin{array}{c}8.90 \\
(2.30-17.1)\end{array}$ & $\begin{array}{c}8.70 \\
(2.30-22.8)^{*}\end{array}$ & $\begin{array}{c}9.80 \\
(3.20-20.0)\end{array}$ & $\begin{array}{c}8.60 \\
(3.90-30.8)\end{array}$ & $\begin{array}{c}8.40 \\
(3.00-16.6)^{*}\end{array}$ \\
\hline & $\begin{array}{l}\text { Serum triglycerides } \\
(\mathrm{mmol} / \mathrm{l})\end{array}$ & $\begin{array}{c}1.51 \\
(0.50-2.90)\end{array}$ & $\begin{array}{c}1.55 \\
(0.70-2.90)\end{array}$ & $\begin{array}{c}1.68 \\
(0.80-3.60)^{*}\end{array}$ & $\begin{array}{c}1.45 \\
(0.35-4.28)\end{array}$ & $\begin{array}{c}1.87 \\
(0.39-8.23)^{*}\end{array}$ & $\begin{array}{c}2.32 \\
(0.59-14.9)^{*}\end{array}$ & $\begin{array}{c}2.19 \\
(0.70-7.86)\end{array}$ & $\begin{array}{c}2.72 \\
(0.35-14.4)^{*}\end{array}$ & $\begin{array}{c}2.91 \\
(0.78-11.5)^{*}\end{array}$ \\
\hline & $\begin{array}{l}\text { Serum total-cholesterol } \\
(\mathrm{mmol} / \mathrm{l})\end{array}$ & $5.44 \pm 0.87$ & $5.41 \pm 0.96$ & $5.20 \pm 0.99$ & $5.03 \pm 1.11$ & $4.64 \pm 0.97$ & $4.72 \pm 1.32$ & $5.10 \pm 1.02$ & $5.21 \pm 1.38$ & $5.20 \pm 1.27$ \\
\hline & $\begin{array}{l}\text { Serum HDL-cholesterol } \\
(\mathrm{mmol} / \mathrm{l})\end{array}$ & N/A & N/A & N/A & $\begin{array}{c}1.39 \\
(0.76-2.48)\end{array}$ & $\begin{array}{c}1.27 \\
(0.68-2.47)\end{array}$ & $\begin{array}{c}1.17 \\
(0.62-2.49)^{*}\end{array}$ & $\begin{array}{c}1.23 \\
(0.70-1.96)\end{array}$ & $\begin{array}{c}1.16 \\
(0.55-2.12)\end{array}$ & $\begin{array}{c}1.23 \\
(0.79-1.88)\end{array}$ \\
\hline & $\begin{array}{l}\text { Serum LDL-cholesterol } \\
(\mathrm{mmol} / \mathrm{l})\end{array}$ & N/A & N/A & N/A & $2.85 \pm 0.88$ & $2.63 \pm 0.78$ & $2.78 \pm 1.05$ & $2.71 \pm 0.81$ & $2.85 \pm 0.82$ & $3.00 \pm 0.93^{*}$ \\
\hline & CIMT (mm) & N/A & N/A & N/A & $0.81 \pm 0.39$ & $0.88 \pm 0.37$ & $0.95 \pm 0.42$ & $0.83 \pm 0.32$ & $0.87 \pm 0.35$ & $1.05 \pm 0.36^{*}$ \\
\hline
\end{tabular}

* p < 0.05 vs. GG; \# p < 0.001 vs. GG; BMI, body mass index; CIMT, carotid intima-media thickness; FPG, fasting plasma glucose; HDL, high-density lipoprotein; LDL, low-density lipoprotein; MS, metabolic syndrome; T2DM, type 2 diabetes mellitus; Data are mean \pm SD or median (minimum-maximum) as appropriate.

associated with serum triglycerides and fasting plasma glucose levels. As a novel feature, in this report we found, that homozygous rs780094 and rs1260326 GCKR gene variants are associated with CIMT.

Table 4 Odds ratios at $95 \%$ confidence intervals $(\mathrm{Cl})$ calculated by the multiple logistic regression analysis models

\begin{tabular}{ccc}
\hline & \multicolumn{2}{c}{ Hypertriglyceridemia } \\
\hline & $\begin{array}{c}\text { Unadjusted model } \\
\text { Odds ratio } \\
\mathbf{( 9 5 \% ~ C l )}\end{array}$ & $\begin{array}{c}\text { Adjusted model } \\
\text { Odds ratio* } \\
\mathbf{( 9 5 \% ~ C l )}\end{array}$ \\
\hline GCKR (rs780094) & 1.748 & 5.335 \\
AA genotype & $(1.256-2.435)$ & $(1.779-15.99)$ \\
GCKR (rs1260326) & $p=0.001$ & $p=0.003$ \\
TT genotype & 1.311 & 4.523 \\
& $(1.078-1.596)$ & $(1.458-14.03)$ \\
& $p=0.007$ & $p=0.009$ \\
\hline
\end{tabular}

*Adjusted for: age, gender, BMI, serum total cholesterol, CAD, statins

\section{List of abbreviations}

BMI: Body mass index; CIMT: Carotid intima-media thickness; CAD; Coronary artery diseases; GCK: Glucokinase; GCKR: Glucokinase regulatory protein; MS: Metabolic syndrome; SNPS: Single nucleotide polymorphisms, T2DM: Type 2 diabetes mellitus.

\section{Acknowledgements}

This work was supported by the grant of Hungarian Scientific Research Foundation, OTKA T 73430 and from grant of Ministry of Health ETT 243/ 2009.

\section{Author details}

12nd Department of Medicine and Nephrological Center, University of Pécs, Pécs, Hungary H-7624 Pacsirta 1. '2Department of Medical Genetics, University of Pécs, Pécs, Hungary H-7624 Szigeti $12 .{ }^{3}$ Department of Radiology, University of Pécs, Pécs, Hungary H-7624 Ifjúság 13. ${ }^{4}$ Central Laboratory, Aladár Petz Hospital, Győr, Hungary, H-9024 Vasvári Pál 2.

\section{Authors' contributions}

MM participated in the design of the study, participated in acquisition of data, prepared and wrote the manuscript, performed the statistical analysis. 
PK, LJ, AM, VCs, NP, ES and KS carried out the molecular genetic studies. EF carried out the ultrasonography examinations. JCs and $\mathrm{KH}$ helped in acquisition of data, IW and BM conceived and coordinated the study. All authors have read and approved the final manuscript.

\section{Competing interests}

The authors declare that they have no competing interests.

Received: 13 September 2010 Accepted: 29 November 2010 Published: 29 November 2010

\section{References}

1. Genuth S, Alberti KG, Bennett P, Buse J, Defronzo R, Kahn R, Kitzmiller J, Knowler WC, Lebovitz H, Lernmark A, Nathan D, Palmer J, Rizza R, Saudek C, Shaw J, Steffes M, Stern M, Tuomilehto J, Zimmet P, Expert Committee on the Diagnosis and Classification of Diabetes Mellitus: Follow-up report on the diagnosis of diabetes mellitus. Diabetes Care 2003, 26:3160-3167.

2. Eckel RH, Alberti KG, Grundy SM, Zimmet PZ: The metabolic syndrome. Lancet 2010, 375:181-183.

3. Matschinsky FM, Glaser B, Magnuson MA: Pancreatic beta-cell glucokinase: closing the gap between theoretical concepts and experimental realities. Diabetes 1998, 47:307-315.

4. Veiga-da-Cunha $M, X u$ LZ, Lee $Y H$, Marotta D, Pilkis SJ, Van Schaftingen E: Effect of mutations on the sensitivity of human beta-cell glucokinase to liver regulatory protein. Diabetologia 1996, 39:1173-1179.

5. Warner JP, Leek JP, Intody S, Markham AF, Bonthron DT: Human glucokinase regulatory protein (GCKR): CDNA and genomic cloning, complete primary structure, and chromosomal localization. Mamm Genome 1995, 6:532-536.

6. Veiga-da-Cunha M, Delplanque J, Gillain A, Bonthron DT, Boutin P, Van Schaftingen $E$, Froguel $P$ : Mutations in the glucokinase regulatory protein gene in 2p23 in obese French Caucasians. Diabetologia 2003, 46:704-711.

7. Køster B, Fenger M, Poulsen P, Vaag A, Bentzen J: Novel polymorphisms in the GCKR gene and their influence on glucose and insulin levels in a Danish twin population. Diabet Med 2005, 22:1677-1682.

8. Vaxillaire M, Cavalcanti-Proença C, Dechaume A, Tichet J, Marre M, Balkau B, Froguel P, DESIR Study Group: The common P446L polymorphism in GCKR inversely modulates fasting glucose and triglyceride levels and reduces type 2 diabetes risk in the DESIR prospective general French population. Diabetes 2008, 57:2253-2257.

9. Orho-Melander M, Melander O, Guiducci C, Perez-Martinez P, Corella D, Roos C, Tewhey R, Rieder MJ, Hall J, Abecasis G, Tai ES, Welch C, Arnett DK, Lyssenko V, Lindholm E, Saxena R, de Bakker PI, Burtt N, Voight BF, Hirschhorn JN, Tucker KL, Hedner T, Tuomi T, Isomaa B, Eriksson KF, Taskinen MR, Wahlstrand B, Hughes TE, Parnell LD, Lai CQ, et al: Common missense variant in the glucokinase regulatory protein gene is associated with increased plasma triglyceride and C-reactive protein but lower fasting glucose concentrations. Diabetes 2008, 57:3112-3121.

10. Spars $\varnothing T$, Andersen $G$, Nielsen T, Burgdorf KS, Gjesing AP, Nielsen AL, Albrechtsen A, Rasmussen SS, Jørgensen T, Borch-Johnsen K, Sandbaek A, Lauritzen T, Madsbad S, Hansen T, Pedersen O: The GCKR rs780094 polymorphism is associated with elevated fasting serum triacylglycerol reduced fasting and OGT-related insulinaemia, and reduced risk of type 2 diabetes. Diabetologia 2008, 51:70-75

11. Tam CH, Ma RC, So WY, Wang Y, Lam VK, Germer S, Martin M, Chan JC, $\mathrm{Ng} M C$ : Interaction effect of genetic polymorphisms in glucokinase (GCK) and glucokinase regulatory protein (GCKR) on metabolic traits in healthy Chinese adults and adolescents. Diabetes 2009, 58:765-769.

12. Diabetes Genetics Initiative of Broad Institute of Harvard and MIT, Lund University, and Novartis Institutes of BioMedical Research, Saxena R, Voight BF, Lyssenko V, Burtt NP, de Bakker PI, Chen H, Roix JJ, Kathiresan S, Hirschhorn JN, Daly MJ, Hughes TE, Groop L, Altshuler D, Almgren P, Florez JC, Meyer J, Ardlie K, Bengtsson Boström K, Isomaa B, Lettre G, Lindblad U, Lyon HN, Melander O, Newton-Cheh C, Nilsson P, OrhoMelander M, Råstam L, Speliotes EK, Taskinen MR, et al: Genome-wide association analysis identifies loci for type 2 diabetes and triglyceride levels. Science 2007, 316:1331-1336.

13. Willer CJ, Sanna S, Jackson AU, Scuteri A, Bonnycastle LL, Clarke R, Heath SC, Timpson NJ, Najjar SS, Stringham HM, Strait J, Duren WL, Maschio A, Busonero F, Mulas A, Albai G, Swift AJ, Morken MA, Narisu N,
Bennett D, Parish S, Shen H, Galan P, Meneton P, Hercberg S, Zelenika D, Chen WM, Li Y, Scott LJ, Scheet PA, et al: Newly identified loci that influence lipid concentrations and risk of coronary artery disease. Nat Genet 2008, 40:161-169

14. Shen H, Pollin TI, Damcott CM, McLenithan JC, Mitchell BD, Shuldiner AR: Glucokinase regulatory protein gene polymorphism affects postprandial lipemic response in a dietary intervention study. Hum Genet 2009, 126:567-574

15. Weissglas-Volkov D, Aguilar-Salinas CA, Sinsheimer JS, Riba L, HuertasVazquez A, Ordoñez-Sánchez ML, Rodriguez-Guillen R, Cantor RM, TusieLuna T, Pajukanta P: Investigation of variants identified in caucasian genome-wide association studies for plasma high-density lipoprotein cholesterol and triglycerides levels in Mexican dyslipidemic study samples. Circ Cardiovasc Genet 2010, 3:31-38.

16. Onuma H, Tabara Y, Kawamoto R, Shimizu I, Kawamura R, Takata Y, Nishida W, Ohashi J, Miki T, Kohara K, Makino H, Osawa H: The GCKR rs780094 polymorphism is associated with susceptibility of type 2 diabetes, reduced fasting plasma glucose levels, increased triglycerides levels and lower HOMA-IR in Japanese population. J Hum Genet 2010, 55:600-604.

17. Qi Q, Wu Y, Li H, Loos RJ, Hu FB, Sun L, Lu L, Pan A, Liu C, Wu H, Chen L, Yu Z, Lin X: Association of GCKR rs780094, alone or in combination with GCK rs1799884, with type 2 diabetes and related traits in a Han Chinese population. Diabetologia 2009, 52:834-843.

18. Dupuis J, Langenberg C, Prokopenko I, Saxena R, Soranzo N, Jackson AU, Wheeler E, Glazer NL, Bouatia-Naji N, Gloyn AL, Lindgren CM, Mägi R, Morris AP, Randall J, Johnson T, Elliott P, Rybin D, Thorleifsson G, Steinthorsdottir V, Henneman P, Grallert H, Dehghan A, Hottenga رل رل Franklin CS, Navarro P, Song K, Goel A, Perry JR, Egan JM, Lajunen T, et al: New genetic loci implicated in fasting glucose homeostasis and their impact on type 2 diabetes risk. Nat Genet 2010, 42:105-116.

19. Nadasi E, Gyurus $P$, Czakó $M$, Bene J, Kosztolányi S, Fazekas S, Dömösi $P$ Melegh B: Comparison of mtDNA haplogroups in Hungarians with four other European populations: a small incidence of descents with Asian origin. Acta Biol Hung 2007, 58:245-256.

20. Grundy SM: Obesity, metabolic syndrome, and coronary atherosclerosis Circulation 2002, 105:2696-2698.

21. Reiling E, van 't Riet E, Groenewoud MJ, Welschen LM, van Hove EC, Nijpels G, Maassen JA, Dekker JM, 't Hart LM: Combined effects of singlenucleotide polymorphisms in GCK, GCKR, G6PC2 and MTNR1B on fasting plasma glucose and type 2 diabetes risk. Diabetologia 2009, 52:1866-1870.

22. Sjögren M, Lyssenko V, Jonsson A, Berglund G, Nilsson P, Groop L, OrhoMelander M: The search for putative unifying genetic factors for components of the metabolic syndrome. Diabetologia 2008, 51:2242-2251.

23. Brown KS, Kalinowski SS, Megill JR, Durham SK, Mookhtiar KA: Glucokinase regulatory protein may interact with glucokinase in the hepatocyte nucleus. Diabetes 1997, 46:179-186.

24. Fernández-Novell JM, Castel S, Bellido D, Ferrer JC, Vilaró S, Guinovart JJ: Intracellular distribution of hepatic glucokinase and glucokinase regulatory protein during the fasted to refed transition in rats. FEBS Lett 1999, 459:211-214

25. de la Iglesia N, Veiga-da-Cunha M, Van Schaftingen E, Guinovart JJ, Ferrer JC: Glucokinase regulatory protein is essential for the proper subcellular localisation of liver glucokinase. FEBS Lett 1999, 456:332-338.

26. Shiota C, Coffey J, Grimsby J, Grippo JF, Magnuson MA: Nuclear import of hepatic glucokinase depends upon glucokinase regulatory protein, whereas export is due to a nuclear export signal sequence in glucokinase. J Biol Chem 1999, 274:37125-37130.

27. Iynedjian PB: Molecular physiology of mammalian glucokinase. Cell Mol Life Sci 2009 , 66.27-42.

28. Perez-Martinez P, Corella D, Shen J, Arnett DK, Yiannakouris N, Tai ES, OrhoMelander M, Tucker KL, Tsai M, Straka RJ, Province M, Kai CS, PerezJimenez F, Lai CQ, Lopez-Miranda J, Guillen M, Parnell LD, Borecki I, Kathiresan S, Ordovas JM: Association between glucokinase regulatory protein (GCKR) and apolipoprotein A5 (APOA5) gene polymorphisms and triacylglycerol concentrations in fasting, postprandial, and fenofibrate-treated states. Am J Clin Nutr 2009, 89:391-399.

29. Stampfer MJ, Krauss RM, Ma J, Blanche PJ, Holl LG, Sacks FM, Hennekens $\mathrm{CH}$ : A prospective study of triglyceride level, low-density lipoprotein particle diameter, and risk of myocardial infarction. JAMA 1996, 276:882-888 
30. Bansal S, Buring JE, Rifai N, Mora S, Sacks FM, Ridker PM: Fasting compared with nonfasting triglycerides and risk of cardiovascular events in women. JAMA 2007, 298:309-316

31. Nordestgaard BG, Benn M, Schnohr P, Tybjaerg-Hansen A: Nonfasting triglycerides and risk of myocardial infarction, ischemic heart disease, and death in men and women. JAMA 2007, 298:299-308.

32. Lundby-Christensen L, Almdal TP, Carstensen B, Tarnow L, Wiinberg N: Carotid intima-media thickness in individuals with and without type 2 diabetes: a reproducibility study. Cardiovasc Diabetol 2010, 20:40.

33. Baumann M, Richart $T$, Sollinger D, Pelisek J, Roos M, Kouznetsova T, Eckstein HH, Heemann U, Staessen JA: Association between carotid diameter and the advanced glycation end product $\mathrm{N}$-epsiloncarboxymethyllysine (CML). Cardiovasc Diabetol 2009, 6:45.

34. Okser S, Lehtimäki T, Elo LL, Mononen N, Peltonen N, Kähönen M, Juonala M, Fan YM, Hernesniemi JA, Laitinen T, Lyytikäinen LP, Rontu R, Eklund C, Hutri-Kähönen N, Taittonen L, Hurme M, Viikari JS, Raitakari OT, Aittokallio T: Genetic variants and their interactions in the prediction of increased pre-clinical carotid atherosclerosis: the cardiovascular risk in young Finns study. PLoS Genet 2010, 6:e1001146.

doi:10.1186/1475-2840-9-79

Cite this article as: Mohás et al:: GCKR gene functional variants in type 2 diabetes and metabolic syndrome: do the rare variants associate with increased carotid intima-media thickness?. Cardiovascular Diabetology 2010 9:79.

\section{Submit your next manuscript to BioMed Central and take full advantage of:}

- Convenient online submission

- Thorough peer review

- No space constraints or color figure charges

- Immediate publication on acceptance

- Inclusion in PubMed, CAS, Scopus and Google Scholar

- Research which is freely available for redistribution

Submit your manuscript at www.biomedcentral.com/submit 